\title{
No Safe Heaven
}

\author{
Yang, Yu-Miao (Corresponding author) \\ Department of Applied English, I-Shou University, No.1, Sec. 1, Syuecheng Rd., Dashu District, Kaohsiung City 84001,Taiwan \\ E-mail: yyangp@isu.edu.tw
}

Received: 16-01-2016

Published: 01-07-2016
Accepted: 08-04-2016

doi:10.7575/aiac.ijalel.v.5n.4p.48
Advance Access Published: May 2016

URL: http://dx.doi.org/10.7575/aiac.ijalel.v.5n.4p.48

\begin{abstract}
Adopted from the Greenwich bombing which had taken place in 1890, The Secret Agent is a dramatic portrayal of the sociological concept of "anomie" - radical disorder in the social structure and consequent personal dislocation. Despite its ironic scepticism, the novel carries with it certain implications for conduct. It does not amount to a political program, any more than it provides to a moral code, but it suggests an ideal social order through its representation of a world with order. This paper thus seeks to explore Conrad's version of a modern world in a state of fragmentation.
\end{abstract}

Keywords: Anomie, Dislocation, Social Order, Conrad

\section{Introduction}

First published as a series in Ridgway's: A Militant Weekly for God and Country, The Secret Agent is a story adopted from the Greenwich bombing which had taken place in 1894. It is, then, not so much a novel about political anarchism as it is a novel about social anarchy. It is a dramatic portrayal of the sociological concept of "anomie" - radical disorder in the social structure and consequent personal dislocation. Despite its ironic skepticism, the novel carries with it certain implications for conduct. It does not amount to a political program, any more than it provides to a moral code, but it suggests an ideal social order through its representation of a world without order. The world of The Secret Agent is thus seen through conservative eyes, as a place in which people exist to deprive or to be deprived. In searching for a safe haven in this jumbled world, every character in this novel is forced into an aimless, endless wandering.

Indeed, the novel offers a vision of a modern world in a state of fragmentation, as if by explosion. It is an ironic vision because Conrad's fundamental social good was the organic community, while we saw the present status of men being that of isolation from each other, alienation from the social whole, and in consequence, loneliness and self-destruction. the dramatic action presents this vision simultaneously in two plots, one in the public, political realm and the other in the private, domestic one. The two plots, and the social sectors they represent, are welded together not so much by their point of contact in Verloc as by the imagery, which is maintained throughout the novel in both plots. This imagery encapsulates the themes of fragmentation and wandering, taking the forms of personal self-enclosure and of physical dismembering (Fleishman, 1976).

\section{Discussion}

The story is staged in London, the city viewed by many often as the centre of the world. Nevertheless, the city of London has a veneer of civilization, but beneath this glorious and glamorous surface, lies treachery and duplicity. In the "Author's Note", Conrad describes the city as "an enormous town ... a monstrous town more populous than some continents and in its man-made might as if indifferent to heaven's frowns and smiles; a cruel devourer of the world's light. There was room enough there to place any story, depth enough for any passion, variety enough there for any setting, darkness enough to bury five millions of lives" (Conrad, 40-1). The process described here serves to expand the role of the city from a mere setting for the action to a medium that expresses the kinds of life lived there. Bound together by no social contract, the dark city represents a web of conspiracies and plots, a dog-eat-dog world of nasty schemers. Beneath its veneer of civility and law, London is revealed as a "heart of darkness". The foggy atmosphere covers and hides Mr. Verloc's movements from all eyes but ours; and it is as if we are compelled to pull aside a curtain which hides repugnant and horrendous sights. For we are introduced to a strange world, which does not exist in the sunlight, which has reality only in the dead of night (Dowden, 1970).

In accord with this conception of London, Conrad selects an anarchist movement as the central focus of this story. Oppressed by the social order, the anarchists seek to overthrow it by violent means and usher in an era of human brotherhood. They are not set against people or classes, but against institutions. The so-called anarchists in the novel are avowedly dedicated to the disruption of the established social order, to the violent breaking-up and disintegration of legality and morality. They are tolerated in London because they represent no real threat. They are simply talkers, always ready to condemn various European governments with words, but actually too lazy to commit any serious acts of dissent. They are smothered in a demoralizing embrace by the British government, their principles reduced to vacant clichés and their programs to private posturings. Their function is to establish the meaning of conservatism, the symbolic value of an ideal and organic community, of a certain kind: to show that such a conservatism is a sufficient, if 
not a necessary, condition for the mutual stability of individual and society. Conservatism in the social sense can be described as a kind of cement, binding individuals together and preventing communities from losing cohesion and continuity, thereby disintegrating into constituent atoms. Yet conservatism must not be taken as a symptom of the weakness of society; on the contrary, it is a mark of its stability, its cohesiveness, and its confidence in itself.

However, the flaws of conservatism must also be borne in mind. Whilst it is the cornerstone of society, providing a sense of security and stability, it also plunges the community into an attitude of reservation, motionless and deep like a 'placid pool' (200), facilitating the appearance of harmony, without addressing the deeper-lying problems. The rottenness of the social system is exposed by two well-chosen characters, the Assistant Commissioner of the police and Mr. Verloc, an apparently respectable married man, who is in fact a spy for a foreign embassy.

In society, especially a conservative one, we often depend on someone virtuous to help us remain decent, because we need the example of others to lead a moral life. The Assistant Commissioner is portrayed as an ideal moral figure, both law executor and protector. He is, in short, a public servant who must follow his conscience, and thus stands for the value of conservatism. Being subjected to a task defined not by himself but by the department to which he belongs and conducted on the basis of instructions from above and reports from above and reports from below, he becomes susceptible to periodic fits of depression. His maladjustment highlights the high degree of organization, integration and institutionalization demanded by the society that stifles him. he is wryly presented as the best the public can expect from its public figures. His function, as a public servant, is to free the individual from the toils of bureaucratic stagnation, yet ironically, he also identifies society's tendency to cramp and frustrate the individual. This tendency emerges sharply when he momentarily escapes its clutches, slipping his official bonds with a pleasurable sense of 'evil freedom' and reverting to the style of his former occupation, plunging into the rainy darkness after Verloc like a hunter into the jungle after his prey. At this moment, the defender of the individual is shown to be a hunter. This kind of reversal implies that at the moment he finds his own form of freedom, the well-respected governor is not much better than the anarchists; and his behaviour points to a corresponding anarchism in government itself.

The central figure of the novel is Mr. Verloc, a secret agent far removed from the James Bond - type figure we might have expected. He must be, to use a rather cliched phrase, a man of honour by instinct, without thinking it, and certainly without saying it. He must be the best man in his world, and a good enough man for any world. if he is a man of honour in one thing, he is so in all things. Unfortunately, Verloc sees himself as a realist on the grounds that he can see through the pretense of morality without any difficulty. As a secret agent who works for the anarchists, the foreign embassy, and the police, Verloc is the main symbol of the duplicity, treachery, and danger at the heart of society. Through Conrad's middle-class, 'respectably married' secret agent, we see the intrigue and secrecy that underlie personal as well as international relations. Every character in the novel hides some of his or her deepest fears and desires, using others as tools to achieve certain personal goals. Mr. Verloc simply carries this tendency to an extreme.

Verloc's wife, Winnie, who does not like looking too deeply into things anyway, is quite in the dark about her husband's secret connections with both the embassy and the police. She is trapped by economic and social circumstance, with a husband whose life is largely closed to her. She has sold herself sexually to Verloc in order to protect her half-witted brother Stevie. Her story may be called A Tale of Two Boats, an apt metaphor for the process by which Winnie's happiness drifts away as she is forces to make a decision between her personal happiness and the security of her family (Daleski, 1977). Winnie's sacrifice in marrying the unromantic Verloc must not be seen as a perverse denial of self and of life. On the contrary, her entire life is imbalanced and precarious by virtue of the distorted notions summed up in her belief that life does not stand much scrutiny. It is an indication not only of her intellectual laziness, but also of her mental weakness. She contrives to maintain an equable soul, remaining blind to her own inner hollowness - as to most other things - and completely unperturbed in her attitude towards the outside world. Winnie's refusal to confront the fact of her life imprisons her in psycho-social isolation, and makes her physically alienated from the rest of the world. Her eyes are opened to the true nature of her husband on the day of the Greenwich explosion when she discovers that Verloc has used Stevie for his own devious purposes, and that the boy has been killed in the process. Stevie's death is the catalyst for the collapse of Winnie's world, a prelude to personal disintegration. 'Her personality' seems to have been 'torn into two pieces'; her 'moral nature' is 'subjected to a shock of which, in the physical order, the most violent earthquake of history could only be a faint and languid rendering' (Conrad, 227). The shock of her brother's death is terrible enough to account for Winnie's collapse, but it is implied that the disintegration is so exacerbated by her habitual vacancy.

Having committed herself to marriage as to a bargain - her loyalty to Verloc in exchange for his protection of Stevie she can only conclude that the contract has been dishonoured, and is therefore null and void. Indeed, she feels so monstrously betrayed that she cannot recognize the man before her as her husband, only as her brother's murderer; and that strong feeling leads her to a mechanical and aimless reaction, an unthinking, destructive act: the murder of Verloc.

Finally and sadly, Mrs. Verloc is compelled to look into things. After the murder, she thinks first of suicide, then of escape - to Spain or California. Wandering alone dark streets, wrecked by physical and mental exhaustion, Winnie is on the verge of another collapse when she meets Comrade Ossipon, the handsome revolutionary. Together they work out a plan of escape. Winnie accepts Ossipon in the first place because she needs something to refill the void which appears so clearly to her after Stevie's death, to bridge her reputed connection with the outside world, and to anchor herself in a chaotic world where she has sacrificed so much for survival. Sadly, her trust in Ossipon does not provide the chance of a brand-new beginning, but another emotional chasm. In the end, betrayed and swindled by Ossipon, forlorn and forsaken, alone in the vastness of a hostile world, Winnie Verloc commits suicide by leaping over the side of the boat 
on which she is attempting to make her escape. Fittingly, her death occurs in the darkness and is referred to as "an impenetrable mystery" and an "act of madness or despair". In Winnie's case, suicide is not only the supreme manifestation of despair, it serves the same end as Jim's suicide in Lord Jim: wandering in search of value and meaning, self-destruction is their last desperate attempt to grasp it. Winnie's suicide is not only her most heartbreaking reproach to Ossipon's betrayal, but also the logical extreme of her pursuit for survival. There is no safe haven for her, and she knows it.

In summing up Winnie's story, we may say that it is essentially a story of disintegration, the disintegration that follows a prolonged period of nullity or vacancy, and issues in the violence of murder and self-destruction. But Winnie's story is also Stevie's. Like Winnie, Stevie leads a vacant life which finally leads to disintegration, and self-destruction.

In contrast to his depiction of Winnie, Conrad describes Stevie as a boy who prefers to go to the bottom of the matter rather than to put his trust in face values. Stevie draws circles while the anarchists discuss the cannibalism of modern society; the circles Stevie draws represent 'cosmic chaos, the symbolism of a made art attempting the inconceivable' (76). The circle is 'inconceivable,' it symbolizes the value of infinity, positioning Stevie as a figure who cannot rest within the social order, tending rather to undermine it. Stevie's circles suggest disorganized perfection, an irrational harmony; they represent his plan of Utopia.

We see the world through the eyes of Stevie, who visualizes himself, Winnie and her husband as living in a 'good' world, quite apart from the one which callously ignores the suffering of the old cabman and his infirm horse. The shop on Brett Street is for him a haven, from this 'bad world for poor people' (Conrad, 169). Stevie, in his half-witted innocence, sees the Verloc dwelling as isolated from the evil of the outside world; whereas in reality it is isolated by its own evil.

The contemplation of the infirm and lonely steed overcame him [Stevie]. Jostled, but obstinate, he would remain there, trying to express the view newly opened to his sympathies of the human and equine misery in close association. But it was very difficult. 'Poor brute, poor people!' was all he could repeat. It did not seem forcible enough, and he came to a stop with an angry splutter: 'Shame!' Stevie was no master of phrases, and perhaps for that very reason his thoughts lacked clearness and precision. But he felt with greater completeness and some profundity. The little word contained all his sense of indignation and horror at one sort of wretchedness having to feed upon the anguish of the other - at the poor cabman beating the poor horse in the name, as it were, of his poor kids at home. And Stevie knew what it was to be beaten. He knew it from experience. It was a bad world. Bad! Bad!

Mrs. Verloc, his only sister, guardian, and protector, could not pretend to such depths of insight. Moreover, she had not experienced the magic of the cabman's eloquence. She was in the dark as to the inwardness of the word 'Shame'. And she said placidly:

'Come along, Stevie. You can't help that' (168).

This passage dramatizes a contrast between two ways of seeing: the normal, practical mode, and the naïve, visionary mode. Furthermore, the difference between Stevie and his sister isn't simply in how they see, but in what they see. Where Winnie merely notices an isolated case of degeneration, Stevie conceives of the poor as part of a closed system of suffering, in which the relief of misery necessitates the infliction of misery. This momentary but appalling vision of society as some kind of pain generator is clearly at odds with the 'normal' life Winnie attempts to foster.

Despite so, Stevie is the only character in the novel who realizes - on some level - the doctrine of compassion. He has been able to discover at first hand, why it is that the world we live in is a bad one for poor people. Stevie's helplessness and idiocy both afford him his capacity for perception and make him an embodiment of what he perceives. Shortly to fall victim to an ignorant and pitiless plot, he illustrates in a general way the social deprivation he laments. In his helplessness he is also the immediate cause behind the novel's central demonstration of the truth he has seen - that is, that poverty gives rise to a 'system' of suffering. Through Stevie's idiotic mind, we see that the cabman's suffering, as well as Winnie's, should acquire encompasses representative resonance, for it forms a link in a pattern of pain that the whole community. Along with millions of other Londoners, living under the shadow of destitution, their love for others requires self-sacrifice.

The most isolated individual in the book, the Professor, is the prototype symbol of alienated man. separated from his family and his nation, he wanders without home, society, or faith. He is a nomad, unable to love and belong. Incapable of love, he subjects himself to a transcendent power and substitutes law for communion, subordination for love. Estranged from himself, the Professor projects all that is good in him onto a strange ideal of making a perfect bomb. In return for this, he gains a new identity, which is symbolized by his adoption of a new name. When other anarchists search for pleasure, he alone seeks pain; when no one else is prepared to pay the full price for their belief, and indeed the price is high, he is willing to condemn society, even as his systematic rejection costs him his sanity.

The characters in the novel are socially dislocated outsiders rather than wanderers. Vladimir has never been attached to society - or at least to what he might call 'civilized'. The urbanity which he parades in various upper-class salons is only a performance - a piece of sustained mimicry; he has no understanding of the real thing. His conversation with Verloc suggests a man spinning in the void of his own conceit, unable to find any purchase on the surface of the social edifice. As for the Professor, he has 'dropped out' of society altogether. In abysmal ignorance of the realities of life, he 
has pursued the rewards of compromise through the practice of inflexibility. His inevitable failure leaves him fanatically convinced of the injustice of cultural institutions, turning him violently against the 'very framework of an established social order'. Both he and Vladimir declare war against the very idea of organized life.

\section{Conclusion}

The explosion at Greenwich is the catalyst which sets the Verlocs' story in motion. It brings the family into sharp focus as the epitome of society, forced apart by their inability to maintain their wholeness under the pressures of chaotic city life. In symbolic terms, however, the explosion carries a further significance. Stevie's death jolts Winnie Verloc out of her complacency. The death is both a tragic loss to Winnie and, in a sense, a symbol of her moral shock. Winnie believes that the facts of life "do not bear much looking into". It is desperate characters like Winnie, who are afraid to confront reality, as well as those, like Kurtz, who try to look too deeply into its dark face, who are often ultimately destroyed in Conrad's novels. Finally, the violent explosion represents the violence at the heart of society and in individuals. It is an irrational act that cuts through all the laws and codes on which society is founded. An entire family - husband, wife, brother - is obliterated, and the stream of life flows on unperturbed. Society, it would seem, survives on the strength of its members' capacity to disregard the madness and despair that infects them.

\section{References}

Batchelor, J. (1994). The life of Joseph Conrad: A critical biography. Oxford: Blackwell.

Conrad, J. (1994). The secret agent: A simple tale. London: Penguin.

Daleski, H. M. (1977). Joseph Conrad: The way of dispossession. London: Faber \& Faber.

Dowden, W. (1970). Joseph Conrad: The imaged style. Nashille: Vanderbilt University Press.

Fleishman, A. (1967). Conrad's politics. Baltimore: The Johns Hopkins.

Gurko, L. (1979). Joseph Conrad: Giant in exile. London: Frederick Muller. 